\title{
Aplikasi E-Kafe Green Market Padang Berbasis Web
}

\author{
Zainul Efendy $^{1 *}$, Mia Nurhayati Idris ${ }^{2}$ \\ ${ }^{1,2}$ Program Studi Sistem Informasi, STMIK Indonesia Padang \\ zainulefendy@stmikindonesia.ac.id*1, MiaNurhayatiIdris@gmail.com²
}

(Received: 5 September 2021 / Accepted: 27 Oktober 2021 / Published Online: 20 Desember 2021)

\begin{abstract}
Abstrak
Proses transaksi dan promosi sangat penting dalam sebuah kegiatan perdagangan, sehingga dibutuhkan sebuah sistem atau aplikasi untuk mengelola proses tersebut agar lebih efisien. Penelitian ini bertujuan untuk menghasilkan aplikasi yang bisa memberikan solusi layanan transaksi dan prmosi pada kafe green market Padang. Metode pengembangan aplikasi mengunakan prototype dengan tahapan analisis masalah, membuat model rancangan aplikasi dan pengujian. Hierarchy input proses output (HIPO) adalah diagram yang merupakan rancangan aplikasi yang telah dibuat mulai dari Entry data, proses data, dan laporan. Sedangkan Entity Relationship Diagram (ERD) dan Context Diagram (CD) adalah untuk memodelkan struktur data dan hubungan antar data. Selanjutnya evalusi system ini diuji menggunakan blackbox testing yang berfungsi untuk mengetahui seberapa jauh berfungsinya komponen komponen atau modul pada sistem tersebut. Hasil penelitian ini berupa aplikasi atau system informasi untuk mempermudah proses transaksi di Kafe Green Market Padang. Sistem ini terdiri dari halaman utama, halaman login, menu entry data, menu transaksi, dan menu konfirmasi pembayaran. hasil evaluasi menunjukkan bahwa system ini sudah berjalan dengan baik, karena setiap komponen sistem Ketika digunakan tidak adanya error. Sehingga sistem ini dapat digunakan dan dimanfaat oleh pengguna.
\end{abstract}

Kata kunci: Aplikasi, Blackbox, Sarana Promosi

\begin{abstract}
Transaction and promotion processes are very important in a trading activity, so it takes a system or application to manage the process to be more efficient. This research aims to produce an application that can provide transaction and promotion service solutions in Padang green market cafes. Application development methods use prototypes with problem analysis stages, creating application design models and testing. Hierarchy input process output (HIPO) is a diagram that is a design application that has been created starting from data entry, data process, and reports. Entity Relationship Diagram (ERD) and Context Diagram (CD) are to model data structures and relationships between data. Furthermore, this system evalusion is tested using blackbox testing that serves to find out how far the component components or modules on the system are working. The results of this research are in the form of applications or information systems to facilitate the transaction process at Kafe Green Market Padang. The system consists of the main page, login page, data entry menu, transaction menu, and payment confirmation menu. The evaluation results show that the system is already running well, because every component of the system when used there is no error. So that this system can be used and utilized by users.
\end{abstract}

Keywords: Application, Blackbox, Promotion Media

\section{PENDAHULUAN}

Perkembangan teknologi informasi semakin hari semakin meningkat dan kebutuhan dunia usaha semakin berkembangan dan interaksi antar interface perangkat keras dan perangkat lunak semakin maju, dan pelayanan informasi membutuhkan layanan serba cepat dan akurat pula, begitu juga dengan kafe green market padang. Kafe ini terletak di jalan tarandam kota 
padang. Setiap hari jumlah pelanggan yang datang semakin meningkat.kadang kala proses layanan transaksi ada yang terlambat. Mereka sangat membutuhkan sistem yang bisa memberikan layanan transaksi harian dalam proses pemesanan dan pembuatan laporannya dan proses promosi berbasis web. Pentingnya peran sistem informasi dalam pengembangan teknologi informasi telah banyak diterapkan di segala bidang dalam penelitian diantara Sistem informasi merupakan perangkat lunak (software) untuk membantu perkejaan dalam rangka meningkat produktifitas hasil kerja yang dalam rangka pengolahan data arsip (Suryadi et al., 2018). Sistem informasi bisa juga diterapkan memberikan layanan layanan promosi pada waterboom kota ternate (Ishak \& Simin, 2016). Perangkat lunak penjualan berbasis web membantu meningkatkan kualitas layanan transaksi (Widagdo et al., 2019). Sistem informasi yang digunakan untuk keperluaan khusus disebut dengan aplikasi, didalam aplikasi hanya digunakan untuk mengatasi satu masalah tertentu, seperti aplikasi absensi, aplikasi stok barang, aplikasi rumah sakit, aplikasi toko obat, aplikasi restoran, dan aplikasi kafe.

Pada artikel ini membahas mengenai Aplikasi e-Kafe Green Market Padang merupakan salah satu model perangkat lunak yang menyediakan informasi mengenai menu makan dan minum serta proses transaksi. Permasalah yang sering yang ditemukan di lapangan adalah proses pemesanan dan pembayaran masih mengunakan kertas, proses pencarian makan yang laris dan proses hasil pembuatan penjualan sering terlambat. Hal tersebut perlu diatasi dengan melakukan promosi dan penyedian informasi dengan menggunakan sistem informasi berbasis web. Kualitas informasi yang cepat bisa meningkat kualitas dari kafe. Sistem informasi merupakan rangkaian sejumlah bagian atau komponen terorganisir yang secara bersama-sama berfungsi atau bergerak menghasilkan informasi yang diperlukan (Efendy et al., 2019). Sistem informasi terdiri dari kumpulan dari sub-sub sistem yang saling terintegrasi dan berkolaborasi untuk menyelesaikan masalah tertentu dengan cara mengolah data dengan alat yang namanya komputer sehingga memberi nilai tambah dan bermanfaat bagi pengguna (Efendy et al., 2019).

Berdasarkan beberapa pendapat di atas dapat disimpulkan bahwa sistem informasi itu merupakan kumpulan komponen yang saling terintegrasi dan berkolaborasi menghasilkan informasi yang sesuai dengan kebutuhan penggunanya. Sistem informasi yaitu sistem yang merupakan kesatuan elemen dengan segala sesuatunya untuk berinteraksi pada satu tujuan kesatuan. Sistem dikatakan satu kesatuan yang berinteraksi jika: (1) antar bagiannya saling terkait dan memiliki kesamaan dalam mencapai sebuah tujuan dari organisasi yang bersangkutan, (2) memenuhi 3 unsur yang terdapat dalam sistem tersebut yaitu: masukan, proses, keluaran. Menurut Lilis dan Puspitasari dalam (Hartono, 2020) mengungpkan bahwa basis data adalah kumpulan data, yang dapat digambarkan sebagai aktifitas dari satu atau lebih organisasi yang berealisasi (Kardinal \& Tasrif, 2018).

Kosasi (2014) telah mengembangkan sistem informasi penjualan berbasis web untuk memperluas pangsa pasar. Selanjutnya, Cahyanto (2018) membuat sistem informasi data rekam medis rumah sakit XYZ dengan menerapkan teknologi web service. Sementara itu, peneliti lain juga telah mengembangkan atau membuat sistem informasi untuk peminjaman ruang dan barang menggunakan fitur sms notification, serta sistem pakar berbasis web untuk diagnosis penyakit gizi (Khasbi et al., 2016; Primasari, 2018; Sopiah, N., \& Agustina, 2018)

Dari literatur dan penelitian sebelumnya, yang langsung membahas mengenai masalah ini di antara penelitian yang dilakukan oleh (Pamungkas \& Yuliansyah, 2017) membahas aplikasi Pos (point of sale) untuk kafe yang diintegrasikan bahasa pemograman php dan database sql lite. Sedangkan penelitian ini dibangun berbasis web mengunakan database mysql dan bahasa pemrograman PHP. Metode perancangan dan membangun aplikasi mengunakan metode prototype. Dimana metode ini digunakan oleh (Alhamidi, 2018) untuk pengembangan aplikasi simpan pinjam.

Berdasarkan hal tersebut di atas, beberapa peneliti sebelumnya telah mengembangkan aplikasi atau sistem untuk perniagaan dan rekam medis. Sementara itu, pada penelitian ini 
bertujuan atau berfokus untuk merancang dan membuat suatu sistem yang bisa membantu melayani transaksi harian pada kafe green market Padang berbasis web, sehingga dapat membantu pihak manajemen kafe green market Padang dan customer.

\section{METODE}

Penelitian ini mempunyai dua tahapan, yaitu metode penelitian dan metode pengembangan. Pada tahapan metode penelitian mengunakan metode teknik pengumpulan data untuk informasi penelitian. Metode pengembangan aplikasi adalah metode prototype. Prototype adalah merupakan suatu metode yang digunakan untuk membangun aplikasi melalui tahapan-tahapan menganalisa masalah yang ada di lapangan, membuat model rancangan sistem yang dibangun mengunakan tool-tools perancangan sistem. Tools yang digunakan diantaranya adalah 1).HIPO, 2).Context diagram, 3).ERD.

Evaluasi dilakukan oleh pengguna untuk mengevaluasi prototype yang dibuat dan dipergunakan untuk memperjelas kebutuhan aplikasi. Metode yang digunakan untuk mengevaluasi hasil rancang bangun Aplikasi e-kafe green market Padang adalah black box testing. Black box testing adalah suatu metode untuk menguji software yang telah dibuat dari aspek fungsional tanpa menguji desain interface dan kode program pada aplikasi tersebut(Afuan et al., 2021; Anggoro \& Hidayat, 2020; Kusrini et al., 2020; Suprapto et al., 2020).

\section{HASIL DAN PEMBAHASAN \\ Hasil}

Pada kafe green market Padang proses transaksi harian pemesanan makan dan minum masih dilakukan secara manual dengan mencatat transaksi tersebut dengan mengunakan kertas kecil atau note, pembuatan laporan transaksi dicatat dengan buku besar, promosi menu makan dan minum yang tersedia hanya mengunakan daftar menu yang diserahkan ke pelanggan. Sering dengan pertambahan pelanggan yang dimiliki oleh kafe green market Padang. Kafe ini mulai lambat dalam memberikan layanan ke pelanggan dan proses laporan transaksi harian makan waktu yang lama dan tidak akurat.

Berdasarkan analisis yang berjalan dibuatlah suatu sistem yang bisa memberikan layanan yang terintegrasi dari pihak manajemen kafe dan customer, pihak kafe bisa mengelola pencatatan data karyawan, data customer, data menu, membuat laporan penjualan, laporan data karyawan, laporan konfirmasi penjualan harian, dari pihak customer bisa memberikan layanan pemesanan melalui sistem.

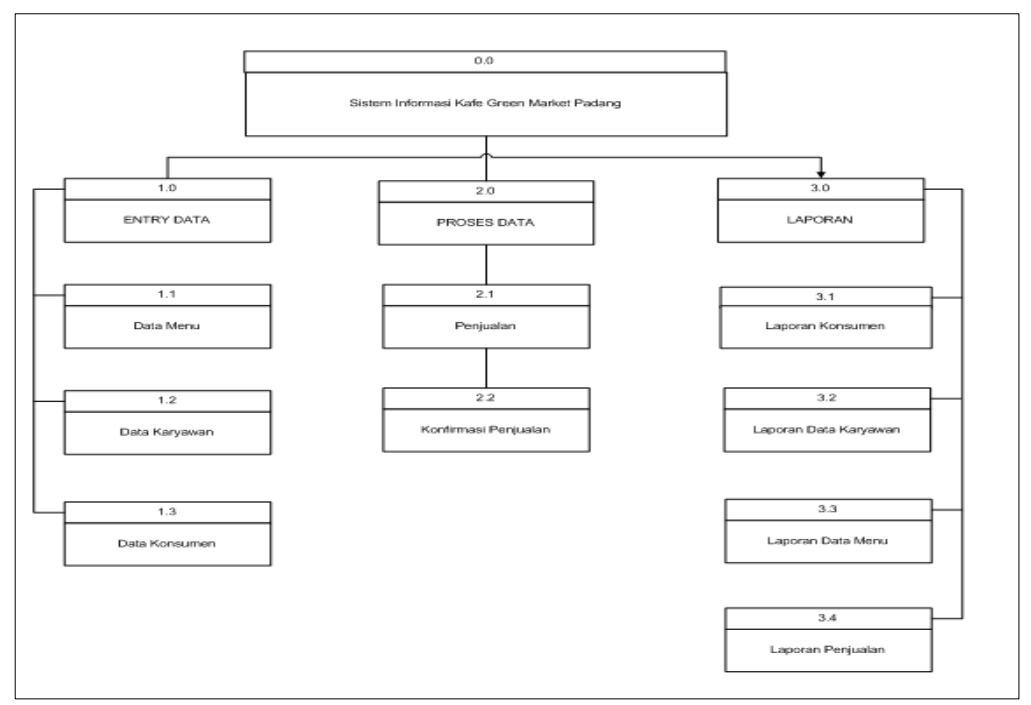

Gambar 1. HIPO Aplikasi E-Kafe Green Market Padang 
Dimana customer melakukan proses pemesanan melalui komputer yang disedia oleh pihak kafe, mereka cukup memilih menu yang tersedia pada layar dan menekan tombol pesan, maka sistem akan langsung memberikan notifikasi ke bagian koki untuk membuatkan pesanan yang diminta dan setelah pesanan selesai pihak koki cukup memberikan notifikasi pada sistem bahwa pesanan sudah selesai, dan pelayanan akan mengantar pesanan kemeja pemesan. Setelah pemesan menerima pesanan beserta bukti kwintasi pemesanan dan pelanggan menyerahkan kwintasi tersebut ke kasir. Setelah itu, pelanggan menyerahkan pembayarannya.

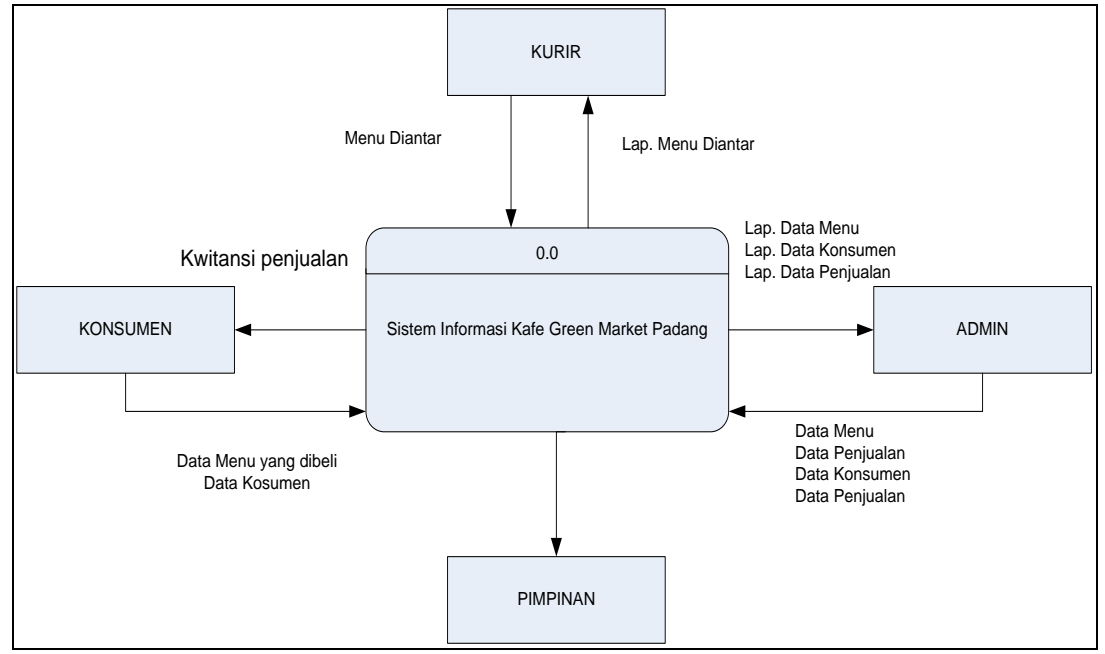

Gambar 2. Contexs Diagram Aplikasi E-Kafe Green Market Padang

Alat yang merupakan gambaran dari modul program yang akan dirancang pada sistem pengolahan data secara komputerisasi digunakan Hierarchy input proses output (HIPO). HIPO Merupakan diagram yang mengambarkan sistem pada Aplikasi E-Kafe Green Market Padang.

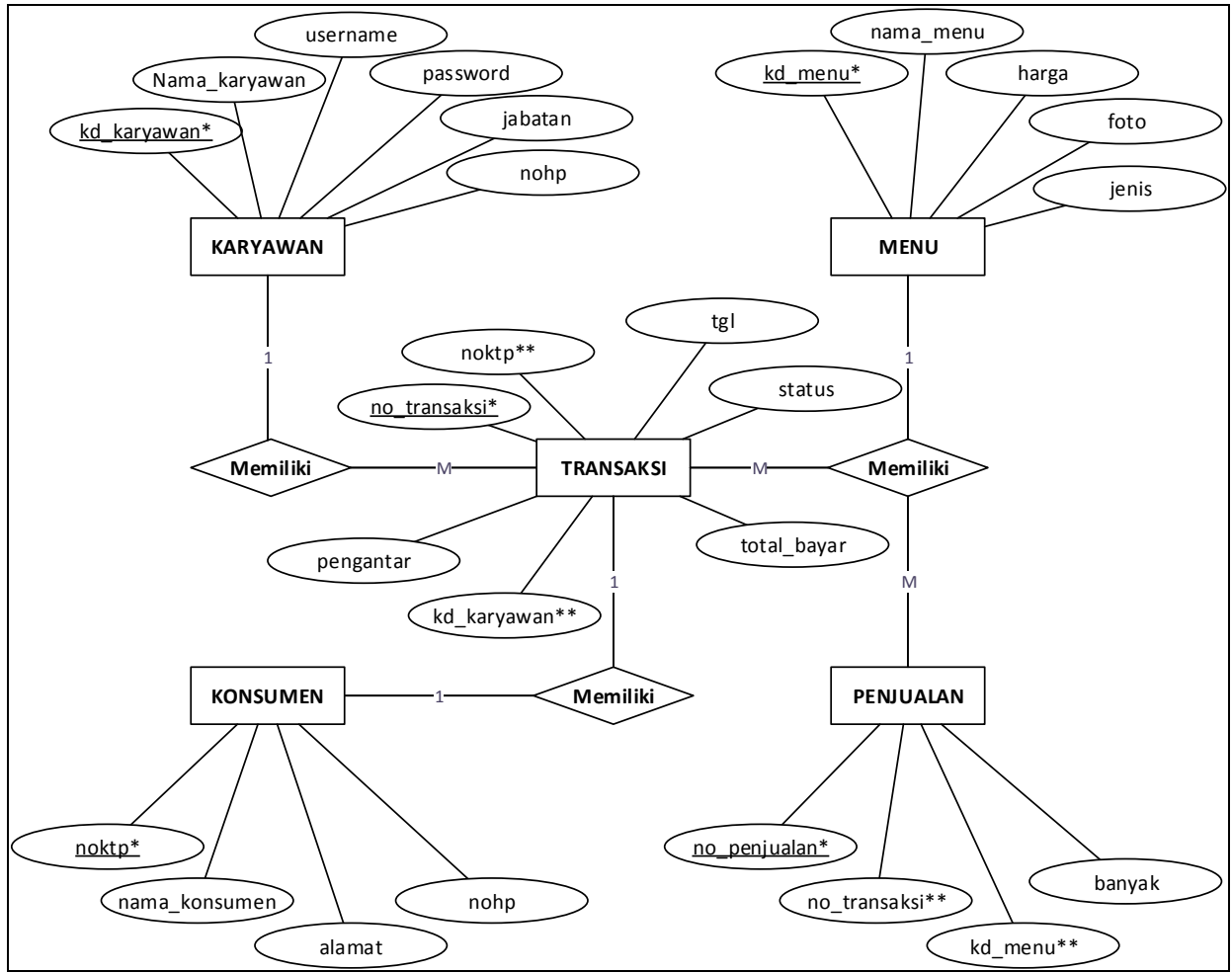

Gambar 4. ERD Aplikasi E-Kafe Green Market Padang 
HIPO pada diagram ini menjelaskan Rancangan global dari sistem yang dibuat mulai dari Entry data, proses data, dan laporan seperti gambar 1. Context Diagram berfungsi mengambarkan aliran data pada sistem. Dengan kata lain, tidak ada aturan baku untuk menggambarkan DFD, tapi dari berbagai referensi secara garis besar terlebih dahulu di buat Context Diagram (CD). CD dan DFD pada sistem informasi Kafe Green Market Padang dapat dilihat pada gambar 2 dan gambar 3.

Entity Relationship Diagram (ERD) berfungsi untuk memodelkan struktur data dan hubungan antar data, dan menggambarkan ERD mengunakan beberapa notasi dan simbol. Agar lebih jelas, ERD sistem informasi Kafe Green Market Padang dapat dilihat pada gambar 4. Perantara untuk ke halaman utama admin yang membutuhkan login terlebih dahulu sehingga tidak semua orang dapat mengakses ke tampilan admin.

Hasil dari aplikasi kami berupa aplikasi atau sistem informasi tampilan halaman utama dapat dilihat pada gambar 5. Pada halaman utama menyajikan informasi mengenai menu yang dimiliki oleh kafe green market Padang, melalui halaman webnya. Pengunjung bisa memilih menu tersebut dengan mengklik salah satu gambar yang menyajikan deskripsi menu tersebut dengan tampilan gambar yang menarik. Selanjutnya Pada gambar 6. Merupakan tampilan form administrator yang memilik akses tertinggi ke aplikasi dimana user ini bisa mengelola proses input menu, pengelolaan data pemesanan, proses konfirmasi pembayaran pemesanan. Selanjutnya, pada gambar 7 menjelaskan mengenai form data menu. User yang berhak mengelola adalah administrator.

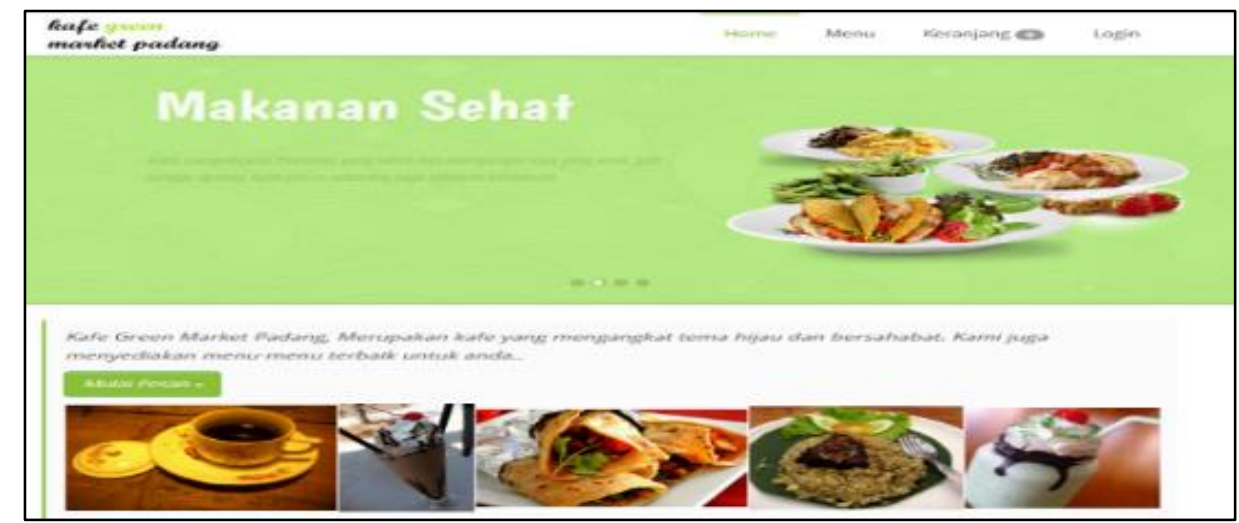

Gambar 5. Halaman Utama

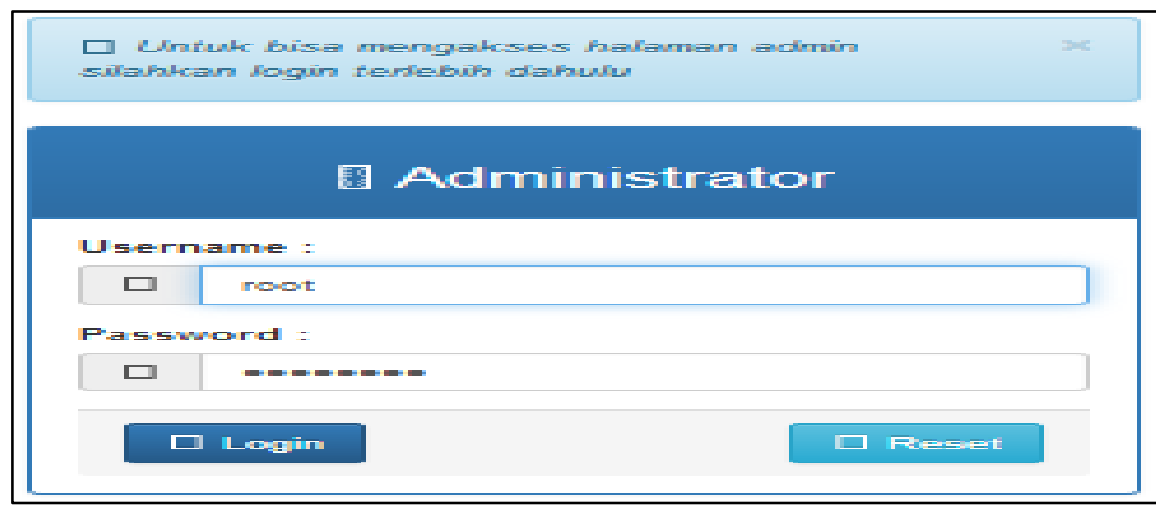

Gambar 6. Form Login Administrator

Pada gambar 8 menjelaskan mengenai data pemesan yang melakukan transaksi ke aplikasi aplikasi e-kafe green market Padang. Lengkap dengan nama, noktp alamat, serta total 
bayar serta dengan proses tombol status transaksi yang dilakukan oleh pemesan apakah telah dibayar, jika telah dibayar maka akan muncul form konfirmasi pembayaran seperti gambar 9 .

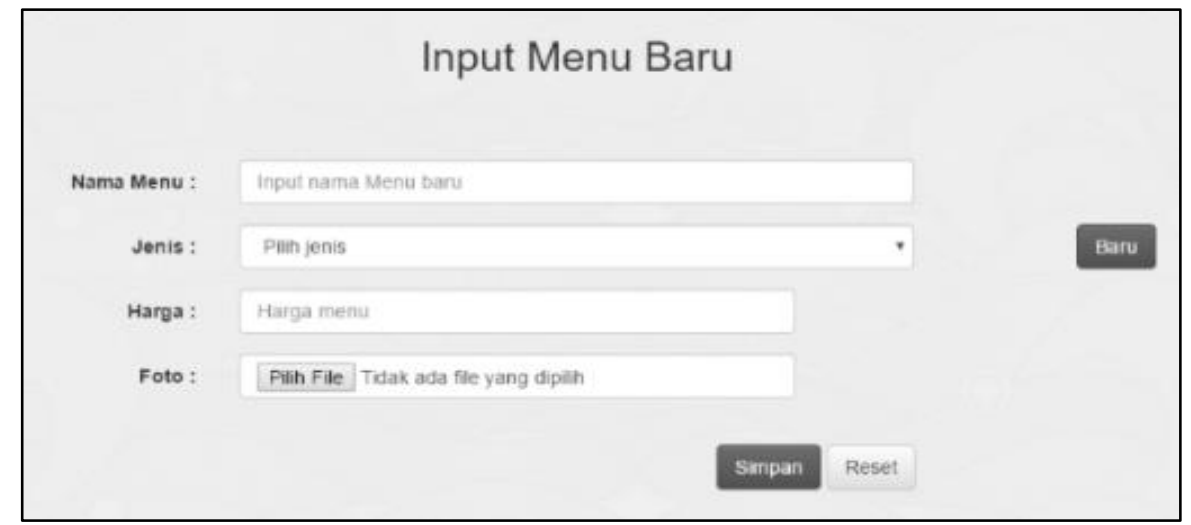

Gambar 7. Entry Data Menu

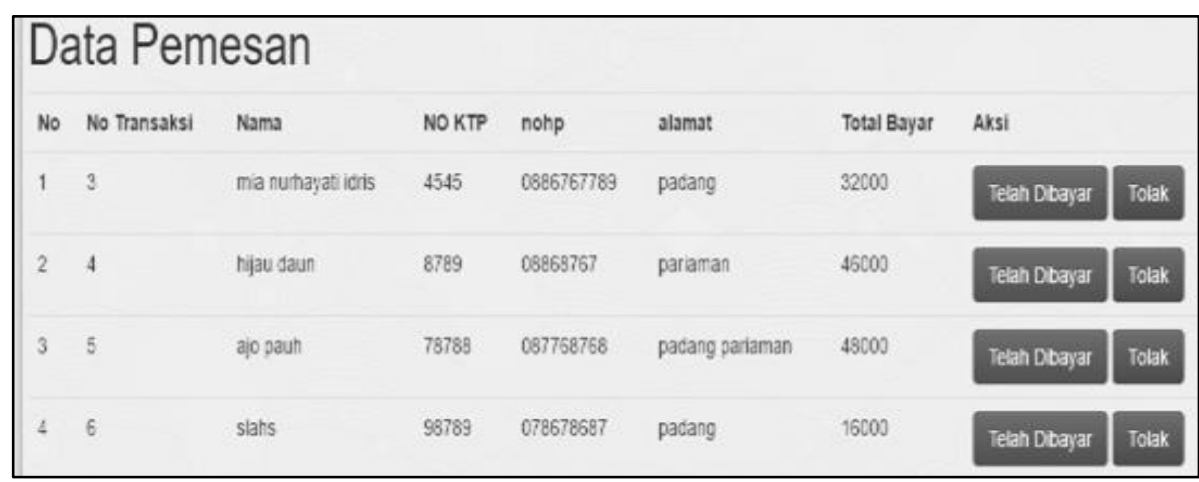

Gambar 8. Proses Konfirmasi Pesanan

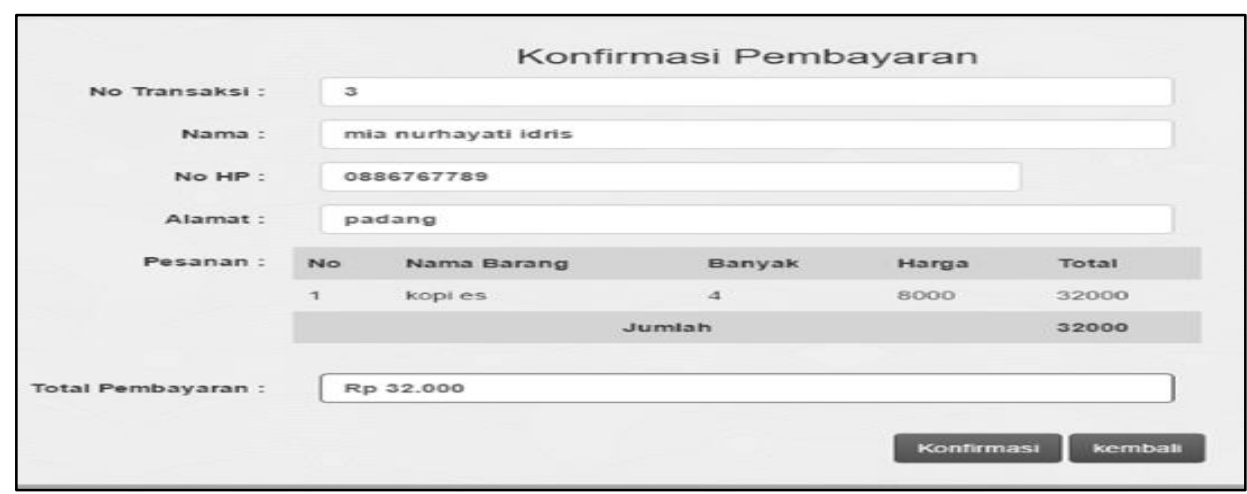

Gambar 9. Proses Konfirmasi Pembayaran

Menu komfirmasi pada aplikasi ini yang nampak pada gambar 9 adalah proses konfirmasi pembayaran jika pembayaran disetujui. Administrator mengklik tombol konfirmasi maka dicetak bukti transaksi pembayaran seperti gambar 10. Pada Gambar 10 menjelaskan mengenai bukti transaksi yang diterima oleh customer jika proses pembayaran telah disetujui dan pihak administrasi juga mendapat bukti tersebut sebagai arsip proses transaksi penjualan.

Pada penelitian ini evaluasi dilakukan dengan menguji aplikasi ekafe green market Padang menggunakan black box testing yang bertujuan untuk mengetahui sejauh mana keberhasilan Aplikasi yang dibangun. Pengujian melibatkan manajemen kafe sebagai pengguna sistem dan customer atau pelanggan. Form yang diuji yaitu form entri menu entri data karyawan, data customer, entri menu, form proses pemesanan, form konfirmasi penjualan, 
form transaksi penjualan, laporan data penjualan, laporan konfirmasi penjualan, laporan data menu, laporan data karyawan, dan laporan laporan customer. Hasil pengujian aplikasi menunjukan keberhasilan aplikasi yang dibangun dalam mempermudah pengelolaan data dan menghasilkan informasi yang efektif dan hasil tersebut nampak pada tabel 1.

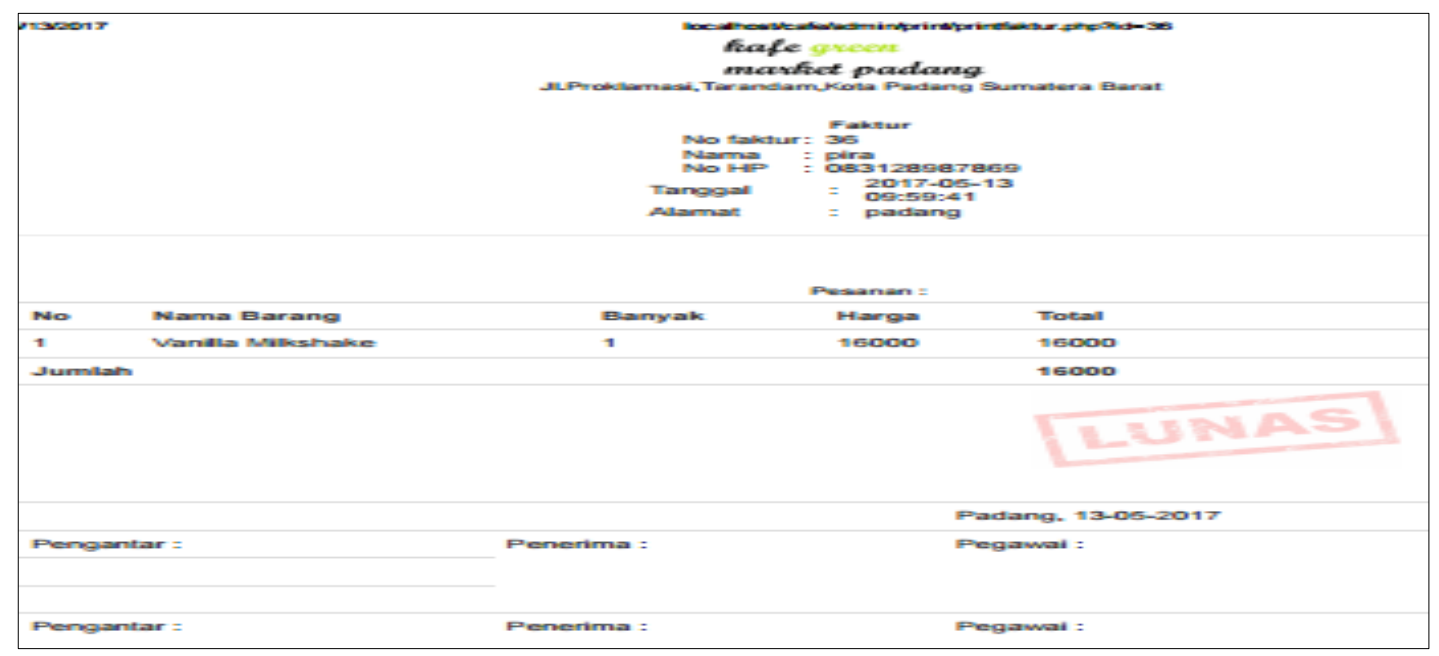

Gambar 10. Print Bukti Pembayaran

\section{Pembahasan}

Hasil Penelitian ini adalah Aplikasi ekafe green market Padang berbasis web. Sistem berhasil dirancang seperti Gambar 5 sampai Gambar10. Gambar 5 merupakan halaman utama yang menjelaskan tentang daftar menu makan yang sediakan oleh sistem. Gambar 6 merupakan bentuk form login administrator yang membatasi penguna mengakses sistem ke halaman utama, pada gambar 6 ini user diminta mengisikan user dan passwordnya lalu menekan tombol login. Jika Password dan user benar maka muncul menu uama administrator untuk mengelola data input menu seperti gambar 7. Pada form ini administrator bisa mengelola data menu yang ditampilkan di halaman utama website. Gambar 8 menjelaskan tentang data pemesanan jenis menu yang dipesan dan total harga yang harus dibayar oleh konsumen dan langkah selanjutnya admin melakukan proses konfirmasi pemesanan seperti gambar 9 dengan menekan tombol konfirmasi pesanan telah diterima. Selanjutnya admin melakukan verifikasi dengan menekan tombol telah dibayar makan dicetak pembayaran merupakan laporan seperti gambar10.

Pada aplikasi ini mempunyai dua user yang berinteraksi kesistem yaitu customer dan administrator dari hasil pengujian mengunakan metode black box. Sistem bisa melakukan proses seperti yang direncanakan setiap modul yang diuji menghasil hasil status berhasil. Proses penelusuran data secara cepat, hasil ini didapat dari pengujian form entri menu, form entri data karyawan, form customer, data form data penjualan. Sementara pengujian form cetak laporan pemesan Penjualan dan laporan konfirmasi penjualan menunjukan informasi yang di tampilkan dalam bentuk laporan hasilnya sudah sesuai dengan transaksi yang ada di aplikasi ekafe green market Padang. Hasil ini sudah sesuai atau relevan dengan hasil temuan (Alhamidi, 2018; Anggoro \& Hidayat, 2020; Pamungkas \& Yuliansyah, 2017; Setiyawan et al., 2015). Bahwa setelah melakukan pengujian menggunakan backbox testing, sesuai dengan apa yang diharapkan.

Sementara itu, pada penelitian sebelumnya (Pamungkas \& Yuliansyah, 2017) membahas pada satu bagian yaitu pada posisi kasir. Kasir mempunyai hak tertinggi beriteraksi dengan aplikasi tersebut. Tapi pada penelitian ini ada 2 aktor yang melakukan interaksi yaitu administrator dan customer. Persamaan penelitian ini dibanding penelitian sebelumnya adalah sama membahas kasus yang sama.dan model pengembangan aplikasi hampir sama. 
Tabel 1. Hasil Evaluasi (Blackbox Testing)

\begin{tabular}{|c|c|c|c|c|}
\hline $\begin{array}{c}\text { Nama } \\
\text { Penguna }\end{array}$ & Modul ujian & Butir ujian & $\begin{array}{c}\text { Jenis } \\
\text { pengujian } \\
\text { sistem }\end{array}$ & Hasil \\
\hline \multirow{6}{*}{ Customer } & Form login & $\begin{array}{l}\text { Verifikasi user dan } \\
\text { password }\end{array}$ & Sistem & Berhasil \\
\hline & Form transaksi Penjualan & $\begin{array}{l}\text { Entri transaksi } \\
\text { penjualan }\end{array}$ & Sistem & Berhasil \\
\hline & Data menu & $\begin{array}{l}\text { Pemilihan menu } \\
\text { transaksi }\end{array}$ & Sistem & Berhasil \\
\hline & Laporan data menu & Melihat data menu & Sistem & Berhasil \\
\hline & Laporan data karyawan & $\begin{array}{l}\text { Melihat data } \\
\text { karyawan }\end{array}$ & Sistem & Berhasil \\
\hline & $\begin{array}{l}\text { Laporan data transaksi } \\
\text { penjualan }\end{array}$ & $\begin{array}{l}\text { Melihat data } \\
\text { transaksi penjualan }\end{array}$ & Sistem & Berhasil \\
\hline \multirow{7}{*}{ Administrator } & Form login & $\begin{array}{l}\text { Verifikasi user dan } \\
\text { password }\end{array}$ & Sistem & Berhasil \\
\hline & Form entri menu & Entry data menu & Sistem & Berhasil \\
\hline & Kelola data karyawan & Entri data karyawan & Sistem & Berhasil \\
\hline & Kelola data konsumen & Entri data konsumen & Sistem & Berhasil \\
\hline & Kelola data Penjualan & $\begin{array}{c}\text { Proses data pen } \\
\text { jualan }\end{array}$ & Sistem & Berhasil \\
\hline & Konfirmasi Data penjualan & $\begin{array}{l}\text { Verifikasi data } \\
\text { penjualan }\end{array}$ & Sistem & Berhasil \\
\hline & Edit user dan password & $\begin{array}{l}\text { Edit data user dan } \\
\text { password }\end{array}$ & Sistem & Berhasil \\
\hline
\end{tabular}

\section{SIMPULAN}

Aplikasi e-kafe green market Padang berbasis web ini telah berhasil dibuat dan bisa memberikan layanan transaksi harian dan layanan promosi menu bagi pihak kafe dan customer, dan aplikasi bisa di akses dengan mudah oleh pengunanya. Oleh karena itu, setelah adanya aplikasi ini bagi pihak kafe tidak memakan waktu dari pada proses sebelumnya yang masing menggunakan manual sebelum adanya aplikasi atau sistem ini.

\section{REFERENSI}

Afuan, L., Nofiyati, N., \& Umayah, N. (2021). Rancang Bangun Sistem Informasi Bank Sampah di Desa Paguyangan. Edumatic: Jurnal Pendidikan Informatika, 5(1), 21-30.

Alhamidi. (2018). Perancangan Sistem Informasi Simpan Pinjam Pada Koperasi Jasa Keuangan Syariah BMT Padang Amanah Sejahtera. JURNAL J - CLICK Jurnal Sistem Informasi Dan Manajemen Informatika, 5(2), 306-319.

Anggoro, D., \& Hidayat, A. (2020). Rancang Bangun Sistem Informasi Perpustakaan Sekolah Berbasis Web Guna Meningkatkan Efektivitas Layanan Pustakawan. Edumatic: Jurnal Pendidikan Informatika, 4(1), 151-160. https://doi.org/10.29408/edumatic.v4i1.2130

Cahyanto, T. A. (2018). Penerapan Teknologi Web Service Pada Sistem Informasi Data Rekam Medis Rumah Sakit XYZ. Query: Jurnal Sistem Informasi, 2(1), 25-32.

Efendy, Z., Putra, I. E., \& Saputra, R. (2019). Asset Rental Information System and Web-Based Facilities At Andalas University. Jurnal Terapan Teknologi Informasi, 2(2), 47-58. https://doi.org/10.21460/jutei.2018.22.103

Hartono, S. B. (2020). Pengembangan Sistem Informasi Arus Kas Dengan Metode Sdlc (System Development Life Cycle) Pada Madin Al-Junnah. ISOQUANT : Jurnal Ekonomi, 
Manajemen Dan Akuntansi, 4(1), 1-16. https://doi.org/10.24269/iso.v4i1.337

Ishak, I., \& Simin, N. S. (2016). Sistem Informasi Profil Berbasis Web Sebagai Media Promosi Pada Waterboom Kota Ternate. IJIS Indonesian Journal on Information System, 1(1), 2130.

Kardinal, K., \& Tasrif, E. (2018). Perancangan Sistem E-Commerce Pada Toko Salsa Sport Berbasis Web. Jurnal Vocational Teknik Elektronika Dan Informatika, 6(2), 37-43.

Khasbi, I., Nugraha, F., \& Muzid, S. (2016). Sistem Informasi Peminjaman Ruang Dan Barang Di Universitas Muria Kudus Berbasis Web Menggunakan Fitur Sms Notification. Simetris: Jurnal Teknik Mesin, Elektro Dan Ilmu Komputer, 7(2), 513-520.

Kosasi, S. (2014). Pembuatan Sistem Informasi Penjualan Berbasis Web Untuk Memperluas Pangsa Pasar. Prosiding SNATIF, 1, 225-232.

Kusrini, W., Fathurrahmani, F., \& Sayyidati, R. (2020). Sistem Pakar untuk Diagnosa Penyakit Ayam Pedaging. Edumatic: Jurnal Pendidikan Informatika, 4(2), 75-84.

Pamungkas, G., \& Yuliansyah, H. (2017). Rancang Bangun Aplikasi Android Pos (Point Of Sale) Kafe Untuk Kasir Portable Dan Bluetooth Printer. Jurnal Sains Dan Teknologi |, 6(1), 199-208.

Primasari, C. H. (2018). Aplikasi Web Sistem Pakar untuk Diagnosis Penyakit Gizi. 1. https://doi.org/10.21460/jutei.2018.12.59

Setiyawan, A., Kodong, F. R., \& Kaswidjanti, W. (2015). Model Aplikasi E-Market Sebagai Sarana Promosi Dan Tukar Menukar Informasi Antara Penjual Dan Pembeli. Telematika. https://doi.org/10.9744/jmk.17.2.109-112

Sopiah, N., \& Agustina, E. P. (2018). Penggunaan Metode Web Engineering dalam Aplikasi Penjualan Kain Khas Palembang. Jurnal Ilmiah Matrik, 20(2), 109-118.

Suprapto, D. D. A., Fauziah, F., Fitri, I., \& Hayati, N. (2020). Pengembangan Aplikasi Sistem Informasi Smart Register Online Berbasis Android Menggunakan Algoritma BruteForce. Edumatic: Jurnal Pendidikan Informatika, 4(1), 47-56.

Suryadi, L., Wahyudi, J., Studi, P., Informasi, S., Informasi, F. T., Luhur, U. B., Utara, P., Lama, K., \& Language, U. M. (2018). Analisa Dan Perancangan Sistem Informasi Penghitungan Pembayaran Ganti Kerugian Lahan Jalan Tol Pada Tim Pengadaan Lahan Kementerian Pekerjaan Umum Dan Perumahan Rakyat Menggunakan Unified Modeling Language. Sintak, 2, 256-265.

Widagdo, P. P., Haviluddin, H., Setyadi, H. J., Taruk, M., \& Pakpahan, H. S. (2019). Sistem Informasi Website Fakultas Ilmu Komputer dan Teknologi Informasi Universitas Mulawarman. Prosiding SAKTI (Seminar Ilmu Komputer Dan Teknologi Informasi), 3(2), 5-9. 